\title{
Od krytyki do ośmieszania - o stosowności w tekstach prasowych
}

Monika Zaśko-Zielińska 


\section{Monika Zaśko-Zielińska}

\section{Od krytyki do ośmieszania — o stosowności w tekstach prasowych}

Z asada stosowności, która jest jedną z fundamentalnych regul retorycznych, porządkuje także codzienne kontakty międzyludzkie oraz kommnikację w mediach. I w każdym z tych obszarów porozumiewania możemy obserwować zmagnania ze stosownością i niepowodzenia w jej respektowaniu, ale - jak piszą retorycy — nie da się zrozumieć stosowności przez studiowanie abstrakcyjnych zasad, a jej poczucie jest wrodzoną zdolnością!

Tekst zatytułowany Od krytyki do ośmieszania ma być próbą pokazania, jak trudno w konkretnej sytuacji - tutaj: śmierci i pogrzebu - sprostać znanym zasadom, utrwalonym nie tylko w normach etycznych czy przepisach prawnych (Karta ('ty'zna medión'), ale przede wszystkim w kulturze. Interesuje muie również, w jaki sposób krytyka wykracza poza przypisane jej granice, a także, czy jest to demonstrowane, czy ukrywane.

Wybrany material prasowy związany jest ze śmiercią Czesława Miłosza i jego pogrzebem. Zawiera teksty opublikowane of 16 sierpnia do końca września $20(04$ roku w "Naszym Dzienniku” (dalej: „NDz”), ale częściowo znane również z przedruków w innych czasopismach, zwłaszcza po wydanym 20 sierpnia oświadczeniu Rady Etyki Mediów w sprawie informacji o śmierci Czesława Miłosza zamieszczonej w „NI)z” 16 sierpnia. Zebrane teksty to artykuly z działu $M Y$ sil jest broniq, wywiad, a przede wszysthim listy do redakcji z rubryk Otrz)-

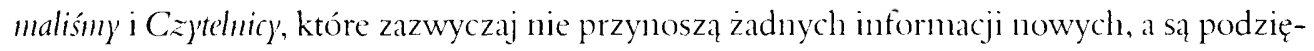
kowaniami za już zanieszczone lub przybierają formę listów otwartych do przeora czy generala paulinów, i powtarzają fragmenty oraz argumenty z wcześniejszych wypowied zi, o czym świadczy na przykład tytul listu: Mam podobnc zdanic. Można odniéść wrażenie, że poszcze- 
gólne listy utrwalają w pamięci czytelników przekazane informacje i budują przekonanie o powszechności tych sądów.

Pierwszą uwag̨, która nasuwa się po przejrzeniu materiałı z „NDz”, jest spostrzeżenie dotyczące niewerbahnych elementów dyskursu. Warto zauważyć, że redakcja chciała przekazać wiadomość o śmierci Miłosza, ale równoczésnie uświadomić czytelnikom swój stosunek do zmarlego - śmierć poety nie jest dla redakcji wydarzeniem najważniejszym. Świadczy o tym po pierwsze umieszczenie tekstu o śmierci poety dopiero na czwartej stronie, i to w jej lewyın dolnyın rogu. Tytuł informacji został zaznaczony najmmiej wyróżniającą się czcionką. Zarówno pod względem usytuowania na stronie, jak i graficznie ważniejsze wydają się kolejno: sprawa budowy Muzeum Narodowego Ziemi Przemyskiej, zwolnienia pracowników zakładu w Opocznie, obchody Sierpnia '80 w Olsztynie. Żaden z artykułów poświęconych Miłoszowi nie został opatrzony jego wizerunkiem. Pojawiło się natomiast zdjęcie profesora Jana Majdy, który obnaża ,prawdziwe oblicze noblisty” oraz dwa zdjęcia kościoła na Skałce. O ile czytelnik może nie uświadomić sobie lokalizacji tekstu na stronie czy zastąpienia wizerunku poety innymi fotografiami, o tyle wyróżnione graficznie tytuły czy tytuliki (lidy) decydują o sposobie czytania całości lub do nich ogranicza się odbiór informacji. I tak na przyklad nagłówki: Antypolskie oblicze Czestan'a Mitosza; Pogrzebanie Skatki; Nie próbom profanacji miejsca u'iecznego spocz)'nku naju'y bitniejszy'ch polskich pisarzy i poetón', czy podpis pod zdjęciem: Bazylika na Skatce - miejsce, które by to czjtelmy'm kompasem dla ducha polskiego — pokazują wybrany przez redakcję dominujący narodowy kontekst przekazu informacji.

Chociaż w Katalogn medión polskich ${ }^{2}$ czytamy, że „NDz” jest ogólnopolskim dziennikiem informacyjno-publicystycznym o orientacji katolickiej i przekazuje codzienne informacje z życia Kościoła katolickiego, to redakcyjna autoprezentacja ${ }^{3}$ zawiera nieco immą hierarchię zainteresowań. Pięć najważniejszych wymienionych kolejno zakresów tematycznych to: Polska i Polacy; kraj i świat; rodzina i Ojczyzna; religia i Kościól; patriotyzm i polityka. Dlatego, ze względu na przeważajacą narodowa perspektywę pisma oraz na to, ze nieodłącznym elementem w wylaniającym się z ,NI)z” autostereotypie Polaka jest jego katolicyzm, do prześledzenia dyskursu o Miłoszu spróbowałam wykorzystać model typowej sytuacji etnicznej, opracowany przez van Dijka, a przedstawiony czytelnikom polskim przez Idę Kurcz ${ }^{+}$. Sytuacja etniczna obejmuje tutaj po pierwsze s c e 11 ę, na którą składają się warunki ogólne (miejsce i czas) oraz okoliczności (kontekst fizyczny i społeczny), a po drugie sam e p i zo d k o n fli k to w y, powstały ze zdarzeń wspóltworzonych przez uczestników i akty negatywne oraz konsekwencje konfliktu. Schemat ten pozwala zarówno zarysować całość sytuacji, jak i wskazać na jawne oraz ukryte elementy dyskursu. Ze względu na wybrany temat najwięcej miejsca zajmą fragmenty poświęcone uczestnikom, gdyż tam zawiera się sposób prezentacji osoby zmarlego, akty negatywne nietypowe dla sytuacji pogrzebu.

\footnotetext{
2Internetowy Kutalog , Vedión Polskich. przygotowywany przez Ośrodek Badań Prasoznawezych Uniwersytetul Jagielloniskicgo (http:/media.onct.pl).

"Na stronic internetowcj: www.naszdziennik.pl.

+ Zob. 1. Kurcz, Znicumość i nicudhommośi stcreotypón'. Warszawa 1994. s. 192.
} 
Czas. Analizowany cykl materiałów związanych z Czesławem Miłoszem rozpoczął się informacją o jego śmierci. Ostatni tekst (autorstwa Jana Majdy) ukazal się 11 października i nosi tytul Ktamliu'a nagonka "Gazety IVyborczej”, a zaczyna siç od stów:

Klakierzy Czesława Miłosza nie przebierają w środkach, żeby zatuszować antypolskie oblicze tego poety...

W świetle publikacji „NI)z” zastanawia przede wszystkim to, kiedy mianowicie, według autorów tekstów, był w Polsce czas Miłosza, bo przecież bezsprzecznie jest on poetą znanym i uznanym. Odpowiedź wskazıjącą na lata osiemdziesiąte znajdıjeny w cytacie:

...wiadomość o literackiej Nagrodzic Nobla dla Miłosza przyjęliśmy z radością jako nagrodę dla Polski i dla „Solidarności”.

Jak przypomina „Życie”, wtedy Miłosz stał się jednym z przywódców zrywu wolnościowego, a nagroda Nobla idealnie trafiala w społeczne zapotrzebowanie. Fragmenty jego wierszy można było wypisywać na sztandarach i transparentach ruchu spolecznego, który zmieniał Polskę 5. Według Jana Majdy sytuacja się zmienila po wydaniu w 20)(12 roku książki jego autorstwa Karol Wojtyta, Wistan'a Szjmborska, Czestan' Mitosz. "N1)z" natomiast rozpoczął kampanię prasową w związku z pochowaniem Czesława Miłosza na Skalce, jak czytany: ze względu na traktowanie śmierci poety jako elementu gry politycznej, prowadzonej przez środowiska prasy „polskojęzycznej”.

Miejsce kontliktu to dla każdego czytelnika przede wszystkim strony gazety, która rozpoczęla dyskusję o pochowaniu noblisty, ale także przywoływana nieustannie przestrzeń narodowa - Ojczyzna. Spośród opisanych przez Jerzego Bartmińskiego" profili pojęcia odnajdziemy koncepcję ojczyzny narodowej, która odwoluje się do więzów krwi oraz wartości wynikających z przynależenia do wspólnoty etnicznej. Jej podstawą jest opozycja „swój” — „obcy", a kultura i sztuka mają być istotnymi składnikami tożsamości narodowej. Do wymienionych przykładowo przez Bartmińskiego składników symbolicznych trzeba tu dołączyć krakowski kościół na Skałce, określany jako „panteon narodowy” czy ,narodowa nekropolia patriotów polskich".

Kontekst fizyczny. O ile w typowych konfliktach etnicznych kontekstem fizycznym jest często broń czy inne narzędzia zagrażające życiu i zdrowiu, o tyle w przedstawianym dyskursie taką funkcję pełni przede wszystkinn sarkofag z ciałem Czesława Milosza, który stal się przyczyną ,pogrzebania Skalki”, i posłıżył do wdarcia się do Bożej świątyni i zawładniçcia sanktuarium narodowym. Czytany:

Czy o. Napiórkowski wiedzial, ze zhańbil panteon Polaków szczątkami Czeslawa Milosza?:

"Mitosz "1' Polsce' '81, „Zycic", 16 sicrpuia 2004.

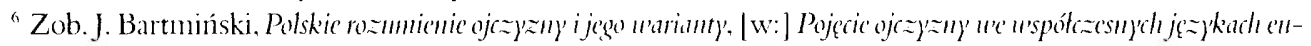
ropcjskich, red. J. Bartminiski, Lublin 1993, s. 36-37. 
...jest to kontynuacja pewnych działań wymierzonych w Kościól święty, cywilizację lacińską i prawdziwie polskį kulturę;

... ponoć organizuje się coś w rodzaju komitetu mającego doprowadzić do eksmisji rażących uczucia Polaków szczątków Miłosza ze Skałki.

Kontekstem społecznym opisywanych wydarzeń jest śmierć i pogrzeb — zdarzenia, których okoliczności wiążą się z zachowaniem odpowiednich postaw, o czym świadczy frazeologizm „opłakiwać czyjąś śmierç” czy utrwalone w polszczyźnie przekłady lacińskich sentencji: „Nie godzi się z umarlych naigrawać”; „o zmarlych trzeba mówić albo dobrze, albo wcale”. W ,NDz” spotkany przeróbki tych tekstów:

O zmarłych trzeba mówić tylko prawdę;

Od prawdy o czlowieku zaufania publicznego nie zwalnia nawet śmierć — oraz caly ciąg zdań, wedlug których protesty przeciwko pochowaniu Miłosza na Skałce są związane z obroną dobrego imienia zmarkego:

Czy nie jest to także kpina ze zmarlego i z jego swoistej tożsamości? Po co mu przyprawiać fałszywą "gębę" narodowego "wieszcza”?;

Nie wolno nadużywać pamięci o zmarłym do niewygasającego w przyszłości w narodzie jątrzenia z powodu miejsca jego pochówku i nieustannego wyprowadzania ze Skalki;

Dlaczego więc na siłę, jakby niepoważnie wobec zmarłego po śmierci przerabia się go na polskiego patriotę i polskiego katolika?

Ośmierci i pogrzebie w „NDz” napisano też, łamiąc zasadę stosowności, że z powodu inauguracji olimpiady w Atenach śmierć poety zeszla na drugi plan; nie bylo poczucia straty. Sam pogrzeb nazwany został między innymi: „oburzającą imprezą pochówku”; ,pochówkiem ciała“; „powodem wstydu dla Krakowa” (dokładnie: „Najwazniejsze wydarzenie stanowiące powód do wstydu dla Krakowa: sam pogrzeb Miłosza na Skakce”); kondukt żałobny nazwano „transportacją zwłok”, a sarkofag Miłosza „elementem promocji miasta”.

Wśród uczestników konfliktu dostrzegamy oczywiście wyrazistą opozycję. MY, podobnie jak w zarysowanym przez van Dijka modelu, ma cechy: pozytywni, tolerancyjni. Grupa MY obejmuje Polaków, katolików, czytelników „NDz”. Najłatwiej opisać ją, odwołując się do wykorzystanych stów sztandarowych ${ }^{7}$ czy symboli kolektywnych ${ }^{x}$. NAS charakteryzuje wolność, uczciwość (..sluszne protesty uczciwych Polaków”), prawdę („Wszystko, co napisa:

..Słowa sztandarowe to wyrazy i wyrażenia. które z racji swojej wartości denotacyjnej i konotacyjnej. a zwla. szcza cmotywncj. nadają siç na sztandary i transparenty, a wiçc do roli $x$ lub y w strukturach typu Niech żjjex

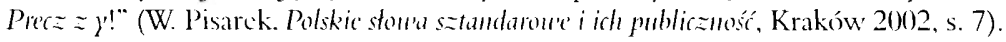

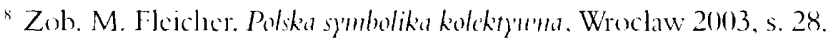


"NDz», jest zgodne z prawdą i ma do tego prawo”), kulturę ( „Krytyka poglądów tego literata jest obroną naszej kultury”), wartości: honor, ojczyzna, wiara (..Naród polski, którego największymi wartościami były są i będą Bóg, honor i ojczyzna. Polak katolik"), patriotyzm (..nasi wybitni patrioci”), naród (.Człowick poza narodem jest antropologicznym kaleką”). NAS określa raczej dostrzeganie wartości nierespektowanych przez innych. Dlatego miranda słowa sztandarowe, które oznaczają treści najlepsze, najpiçkniejsze, najwartościowsze" są tutaj nieliczne. Spośród 54 pojęć wymienionych w pracy Walerego Pisarka można wskazać: uczciwość, ojczyznę, prawdę, godność, patriotyzm, walkę.

ONI, a raczej ON (Czestaw Milosz) i jego „środowisko”, „obrońcy” i „klakierzy”, „Gazeta Wyborcza", Adam Michnik - zagrazają: wolności, rodzinie, dobru, kulturze, ojczyźnie, patriotyzmowi, tradycji, narodowi, Kościołowi; gwalca normy. Charakteryzowani sa przez condemnanda, czyli wyrazy, które oznaczają treści najgorsze, nieprzyjemne i najszkodliwsze" Do oceny Miłosza wykorzystano między innymi słowa: kommnizm, kommma („trzymał z komunistami”; „nie miał oporów, by przylączyć się do komunistów”; ,był komunistyczuym dyplomatą"); lewica (,wstapil tam nawet do lewicowego ugrupowania”); aborcja (.publicznie wspieral i propagował aborcję"). Relacja między NAMI a NIM/NIMI ksztaltowana jest przy użyciu określeń-etykiet narodowościowych, które obejmują wiązki cech i silnie działają na wyobraźnię:

a. Polak; anty-Polak Miłosz; paszkwilant polskości; „polski” noblista; antypolska działalność;

b. Litwin; ten Litwin noblista; czul się bardziej Litwinem czy też „Baltem”; obywatel Litwy.

Mimo nasuwającego się tutaj stereotypu Litwina, którego negatywne cechy to między innymi: nieprzewidywalność, mściwość, skłonność do manipulowania historią na wlasıy użytek, akceptacja działań nacjonalistycznych, hipokryzja" - trzeba raczej uznać, że chodzi tı szczególnie o podkreślenie obcości w ogóle, wzmacniane dodatkowo użyciami:

- „Europejczyk” („A może stali się doskonałymi «Europejczykani», jak ten, który niedawno w telewizji dowodził, że być „Europejczykiem”, to czuć się we wlasnym kraju jak cudzoziemiec?");

- cudzoziemiec; kosmopolita; środowiska kosmopolityczno-libertyńskie; wynarodowiony; antynarodowa sitwa;

- Żyd („byl ściśle związany z Żydami i sprawami Żydów”);

- mason (.Ciekawe, czy był wtajemuiczony?”);

- „obcy” jako przeciwieństwo ,naszych” (,jeżcli nie są "świniami”, to są na

\footnotetext{
${ }^{4}$ Zob. W. Pisarck, op. cit, s. 26.

to Zob. ibidem. s. 28.

$"$ Zub. C. Okińczyc, Sterotyp Lituina w ocah Polaka, [w:] Varody i stercotypy', red. T. Walas, Kraków 1995.
} 
pewno ludźmi obcego pochodzenia, którzy dokonują w Polsce jakiegoś duchowego i ideologicznego desantu").

Charakterystyczna jest też sytuacja, w której domaganie się szacunku wobec zmarłego utożsamia się z zasadani „politycznej poprawności”, traktowanej jako obca:

...ale jak wytlumaczyć zachowanie niektórych osób duchownych, dla których poprawność polityczna, a nie prawda, jest wartością nadrzędną? Przykre to i niezrozumiałe dla nas, Polaków katolików. Szczęść Boże!

Sądzę, że Rada Etyki Mediów jest podporządkowana politycznej poprawności, stąd oburzenie na wypowiedź ..Naszego Dziennikia”.

Reprezentıjąca NAS grupa ludzi oprócz opozycji „swój” — „obcy” sięga również po inne argumenty. Jednym z nich są zdania wykorzystıjące k r a ń c ow y blą d a t r y b u c j i dotyczący spostrzegania międzygrupowego, który polega na tym, że:

...negatywne dzialania czlonków grupy obcej przypisywane są ich wewnętrznym dyspozycjom w większym stopniu niż negatywne działania czlonków własnej grupy, a pozytywnych działań członków obcej grupy upatruje się w czynuikach niedyspozycyjnych, np. dużym wysiłkı, kontekście sytuacyj$11 y 111^{12}$.

I tak Miłosz otrzymał nagrodę Nobla tylko dzięki sprzyjającym okolicznościom, szczęściu, przypadkowi (,Nikt nie mial wątpliwości, że bez gdańskich robotników nie byłoby Nobla ani dla Miłosza, ani dla Walęsy”), a MY ,mimo tych zastrzeżeń potraktowaliśmy z góry Milosza - nieznanego wówczas w kraju poetę - jak wieszcza i orędownika sprawy narodowej, bo t a k p r z y w y k l iśm y traktować stawnych Polaków, zwłaszcza noblistów" (dziatanie pozytywne).

Porównywanie zachowań i dzialań stron MY i ONI odbywa się w tym wypadku także dzięki zestawianiu konkretności i abstrakcyjności, gdyz — jak pisze Ida Kurcz — używanie terminów (czasowników, przymiotników) abstrakcyjnych sprzyja generalizowaniu danego zachowania na różne sytuacje, a zachowaniu opisanemu w kategoriach abstrakcyjnych i szerokich jest znacznie trudnicj zaprzeczyć ${ }^{13}$. Działanie pozytywne NAS określane jest przy użyciu wyrazów abstrakcyjnych, a negatywne (czyli to jednostkowe) - konkretnych, odwrotnie zaś w stosunku do NIEGO: pozytywy — wiążą się z konkretnością, negatywy — z abstrakcyjnością, na przyklad:

Bo wprawdzie przethumaczyl wiersze paru polskich poetów i wydal je w USA (to jedyna jego zasługa), ale jako wykładowca literatury na uniwersytecie

'2 C. N. M. Macrae, Ch. Stangor, M. I tewstonc. Sterety'py' i upreedzenia, tl. M. Majchrzak (i in.), Gdańsk 1999 s. 54 .

Zob. I. Kurcz. Psyrhologia jezyka i kommikacji. Warszawa 2000, s. 208. 
w Berkeley i autor pseudopodręcznika w języku angielskim - Historia literatury' polskiej oraz jako oceniający polskich pisarzy w swoich eseistycznych książach - Milosz ujawnil się jako naukowy ignorant i paszkwilant naszej literatury.

Ze względu na to, że o Miloszu pisze się w "NI)z” raczej źle, więcej jest więc stwierdzeń z czasownikami abstrakcyjnymi niz konkretnymi, jak choćby:

Tymczasem Milosz nie z miłości do Polski, lecz z awersji uprawial wobec nas totalną krytykę;

...dyskwalifikowat i bezcześcił nasze narodowe wartości;

...pochwalał i aprobowal gorszące parady gejów i innych zboczeńców.

Podkreślanie szlachetıości NAS odbywa się natomiast przy użyciu strateggii kamuflażu, nazwanej przez van Dijka strategia „tak, ale”, jak w przykladach:

Nie mam nic przeciwko grzebaniu zmarlych i obdarzonemu talentem poecie należy się jakiś pochówek, ale niechby to było gdzie indziej, choćby w podziemiach stalinowskiego Pałacu Kultury i Nauki, ale nie w świętym miejscu;

Czesław Miłosz ma swoje miejsce w literaturze, ale nie polskiej, mino że pisal po polsku.

Strategia „tak, ale” mieści się wśród a k tów ne ga tyw ny ch, tworzących sytuację konfliktową, która z perspektywy nadawców jest łańcuchem negatywnych i pozytywnych dzialań, z tym że pozytywne przypisywane są NAM. I tak sytuacja konfliktowa analizowanego dyskursu obejmuje następujące wydarzenia:

- informacja o śmierci Czestawa Milosza;

- ıjawnienie przez Jan Majdę antypolskiego oblicza Miłosza (pozytywne):

- niestosowna propozycja pochowania Mitosza na Skatce (negatywne):

- apele do przeora paulinów o niewyrazenie zgody na pochowanie noblisty w sanktuarium Narodu (pozytywne);

- oświadczenie Rady Etyki Mediów: „Rada Etyki Mediów, a wcześniej pani $M$. Bajer w napastliwych i calkowicie pozbawionych argumentów merytorycznych słowach skrytykowala redaktorów «Naszego I ziemnika» w związku z przeprowadzonym wywiadem z pracownikiem nankowym UJ" (negatywne);

- protesty i ostre sprzeciwy najszlachetniejszych i najznakomitszych autorytetów - ludzi ziemi krakowskiej i z calego świata (pozytywne);

- miękki przeor paulinów ugiąl się i zgodzil się na pochówek anty-Polaka Mitosza;

- groźby demonstracji w dniu pogrzebu i doprowadzenia do eksmisji szczątków. 
Jak pisze van Iijk, w konfliktach etnicznych nie ma pomysłów na rozwiązanie sporów, dochodzi natomiast do pogwałcenia zasad i wartości. Warto dodać, że obserwatorzy przedstawionego dyskursu reagowali na publikacje „NDz” różnorodnie:

Nie chodzi tu o to, że zwyczajem jest mówić o zmarłym dobrze, a zwyczaj ten „Nasz Dziennik” złamał. Chodzi o podeptanie człowieka, próbę obrzucenia go błotem klanstwa i wyrzucenia na śmictnik historii...

Mnie jest jednak przykro, że zmarl poeta i pisarz o dużym talencie doceniany za granica, a 11 nas niestety szkalowany ${ }^{1+}$.

Na forum internetowym można bylo też przeczytać:

W sumic to zaczynam się zastanawiać, kto tu ma rację, bo obie strony prezentują skrajne opinie dotyczące tematu.

Trzeba też przypomnieć, że okresie konfliktı opublikowano oświadczenie spowiednika Milosza, które według „Gazety Wyborczej” przyjęte zostalo jako próba uspokojenia środowisk protestıjących przeciwko pochowaniu Miłosza na Skałce.

Jak pisze Ida Kurcz, stereotypy można za pomocą języka wywolywać, ale — co widać nie zawsze można je świadomie kontrolowack ${ }^{15}$, co pokazują wykorzystane strategie, wylonione z dyskursu „NDz”. Publikacje „NDz” są przede wszystkim dowodem, że w sytuacji ataku na wartości narodowe według nadawców dopuszczalne jest zawieszenie wszelkich norm, a wśród nich zasady stosowności, gdyz:

- spór o miejsce pochowania Czesława Miłosza trwał w „NI)z” ponad miesiąc;

- prezentacja osoby zmarłego poprzez dobór treści i słownictwa odbiegała od utrwalonego w kulturze;

- nie uwzględniono imnych punktów widzenia odbiorców dyskursu;

- ostatni tekst (Kłamliu'a nagonka "Gazety" IVyborzej») że ofiarą dyskursu jest udzielający wywiadu Jan Majda, a publikacje „Gazety Wyborczej” wymagaja sprostowań.

Można więc uznać, ze między krytyką a ośmieszaniem mieści się też celowość lub nieświadomość nadawcy, bo - jak powiada Cyceron:

...jak w życiu, tak w wymowie nic nie jest trudniejsze, jak rozpoznać, co przystoi. 